\title{
GROBLJE IZRAELITIČKE BOGOŠTOVNE OPĆINE U POŽEGI
}

\section{Sažetak}

Ovaj rad bavi se sudbinom izraelitičkoga/židovskoga groblja u Požegi od njegova osnutka, razdoblja devastacije i pokušaja likvidacije pa do konačne rekonstrukcije i obnove krajem 2005., odnosno 2006. godine. Izraelitičko groblje u Požegi gotovo je jedina uspomena na nekad veliku židovsku zajednicu koja je imala važnu ulogu u gospodarskom, kulturnom i društvenom životu grada Požege u vremenu od kraja 18. stoljeća pa do Drugoga svjetskog rata. Rad se uglavnom temelji na arhivskom gradivu Hrvatskoga državnog arhiva u Osijeku, Državnog arhiva u Slavonskome Brodu - Odjel u Požegi te Jevrejskog istorijskog muzeja u Beogradu. Prvi pokušaji obnove groblja datiraju iz 50-ih godina prošloga stoljeća obraćanjem potomaka požeških Židova Narodnom odboru gradske općine Požega s molbom za uređenjem groblja, što se sve do 2005. godine nije realiziralo. Konzervatorskim istraživanjem židovskoga groblja započetim 2004. godine u smislu sustavnog popisivanja, fotografiranja i identificiranja spomenika na terenu, uz obradu židovskih matica umrlih, postavili su se temelji za izradu projektne dokumentacije za rekonstrukciju groblja, te je groblje u konačnici obnovljeno i zaštićeno kao kulturno dobro Republike Hrvatske.

Ključne riječi: izraelitičko/židovsko groblje; obnova; konzervatorska istraživanja.

\section{Uvod}

U materijalnom smislu izraelitičko/židovsko groblje u Požegi jedini je očuvani trag postojanja nekad razmjerno velike židovske zajednice koja krajem 18. stoljeća potiho nastanjuje sela oko grada Požege, dok u grad dolaze po jedan ili dvojica pripadnika te zajednice u vrijeme velikih sajmova zadržavajući se dan ili dva. ${ }^{1}$ Tek po-

1 Kempf, Julije (1910): Požega: zemljopisne bilješke iz okoline i prilozi za povijest slob. i kr. Grada Požege i Požeške županije, str. 566. 
četkom 19. stoljeća može se govoriti o stalnom naseljavanju Židova u grad Požegu. U prvoj godini 19. stoljeća na području Požeške županije bilo je nastanjeno 16 osoba židovske vjere, a taj je broj s vremenom rastao. ${ }^{2}$

Povijesni kontekst naseljavanja Židova u Požegu, kao i njihov vjerski, kulturni i gospodarski život, tema je kojom su se bavili pojedini povjesničari raspolažući rijetkim dokumentima i podacima iz arhiva i tek usputno spominjući i židovsko groblje. Rad na ovoj temi započeo je još 2003. godine obradom dostupnih matičnih knjiga umrlih, istraživanjem arhivske građe $u$ Državnom arhivu u Slavonskome Brodu Odjel u Požegi, a 2004. godine i terenskim radom na samom groblju, što je uključivalo popisivanje grobnih mjesta i sustavno fotografiranje kako bi se komparacijom podataka iz Matice umrlih i stanja "na terenu" utvrdio broj pokopanih.

Istraživanje u Jevrejskom istorijskom muzeju u Beogradu provela sam 2007. godine zajedno s kolegom Borisom Maringerom, dokumentaristom u Konzervatorskom odjelu u Požegi, a riječ je o građi koja se velikim dijelom odnosi na razdoblje nakon Drugoga svjetskog rata.

\section{POVIJEST IZRAELITIČKOGA GROBLJA}

Za nastanak židovskoga groblja u Požegi zaslužan je Mojsije Rosenberg, prvi Židov koji se trajno naselio u Požegu unajmivši kuću u Sudačkoj ulici (danas Gupčeva ulica) na trideset godina, baveći se trgovinom, a kasnije svjećarskim i sapunarskim obrtom. Julije Kempf u svojoj monografiji Požega navodi kako je Gradsko zastupstvo na zahtjev Rosenberga dodijelilo zemlju za groblje izvan grada na zapadu, tik uz državnu cestu Požega - Pakrac, gdje se ono još i danas nalazi, no nigdje se ne spominje točna godina osnutka groblja. Zagrebački rabin Gavro Schwarz u članku objavljenom u Glasniku Županije požeške br. 43 iz 1901. godine piše: „Porodica je Rosenberg utemeljiteljica židovskog bogoslužja u Požegi, a sigurno je ona kupila židovsko groblje, onaj na ime dio današnjeg groblja, koji je u ravnici blizu ceste, jer je u ovom dijelu grob Mojsije Rosenberga, dok se od grad. obćine moli proširenje groblja godine 1846." Na temelju odluke Gradskog zastupstva groblje je prošireno i 1872., pri čemu je zastupstvo odredilo novu površinu od 150 četvornih hvati prema jugu te darovalo 30 hrastovih stupaca za podizanje ograde.

Svoj konačni oblik groblje dobiva 1906. godine, kada je obzidano zidom od kamena i opeke.

2 Žugaj, Vjekoslav (2001): Židovi novogradiškoga kraja, Židovska općina Zagreb, Zagreb, 2001. 


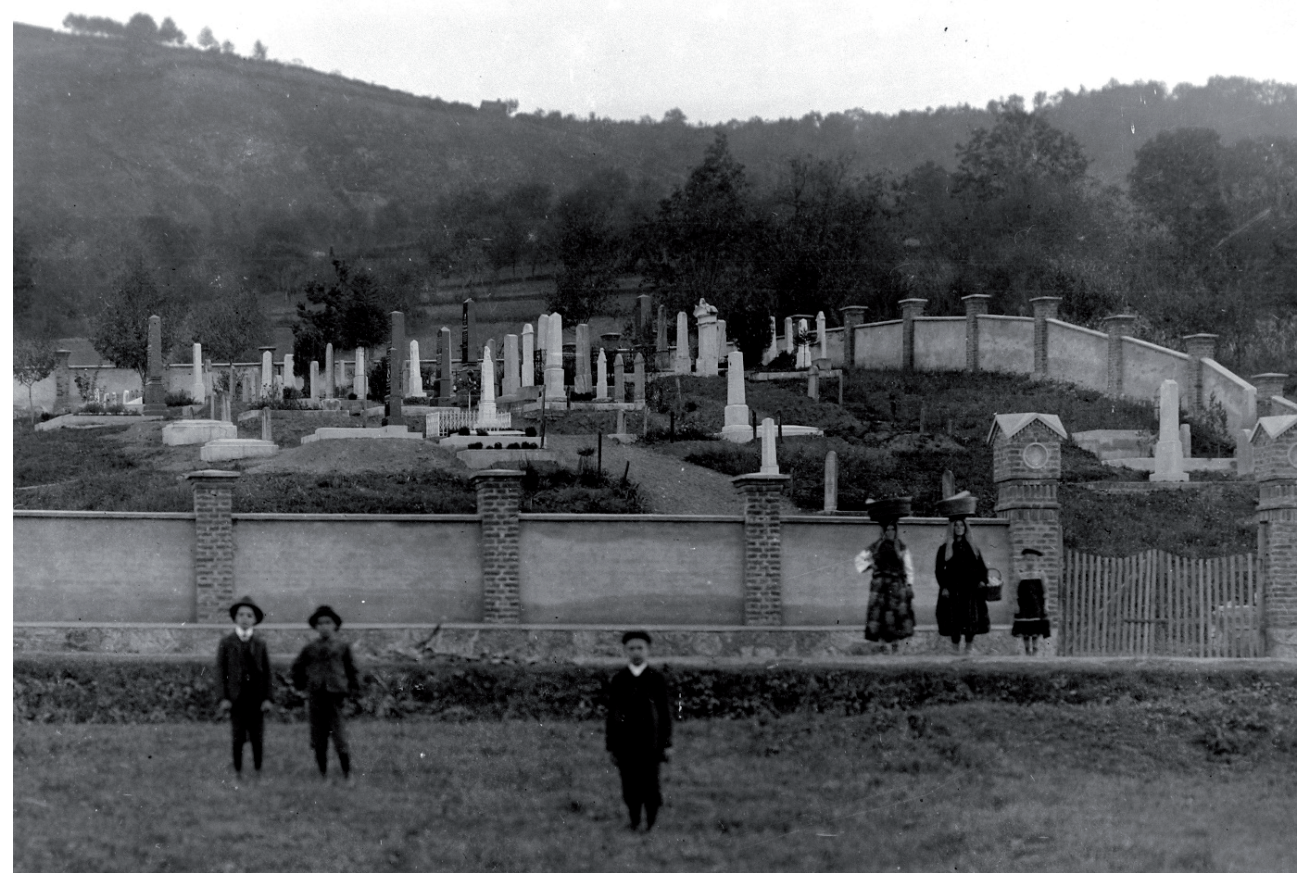

Židovsko groblje, fotografija Julija Kempfa

Pregledom fonda Saveza jevrejskih opština u Jevrejskom istorijskom muzeju u Beogradu, u knjizi Katastar, koja sadrži popis svih židovskih groblja s područja bivše Jugoslavije, stoji podatak da je židovsko groblje u Požegi osnovano 1840. godine. U Vjesniku Kraljevskog Hrvatsko-Slavonsko-Dalmatinskog zemaljskog arhiva X/1908., u prvom dijelu teksta Prilozi k povijesti Židova u Hrvatskoj, koji govori o naseljavanju Židova u Požegi, Gavro Schwarz govori o tome kako se u starom dijelu groblja nalaze spomenici članova obitelji Rosenberg i rabina Krakauera te nekoliko humaka bez nadgrobnih spomenika, pogrešno navodeći 1844. kao godinu smrti Mojsija Rosenberga. Tome u prilog govori vrlo zanimljiv podatak koji je pronašao kolega Boris Maringer prilikom istraživanja građe $u$ požeškom Odjelu Državnog arhiva u Slavonskome Brodu, gdje u apelu za smanjenje tolerancijske takse upućenom Gradskom magistratu grada Požege 15. travnja 1839. udova Amalia Rosenberg kao otegotnu okolnost u poslovanju navodi činjenicu da je njezin suprug Mojsije poginuo 6. ožujka $1834 .^{3}$ Prema tome možemo zaključiti da je požeško židovsko groblje

3 Sign: HR-DASB-PŽ-2 Poglavarstvo Kraljevskog i slobodnog grada Požege (1765-1848), Opći spisi, kut. 135 , spis $753 / 1839$. 
svakako nastalo prije 1834. godine, što bi značilo da je jedno od starijih u ovom dijelu Slavonije. Zanimljivo je da je i rabin Salomon Krakauer, kao drugi najvažniji član izraelitičke zajednice $\mathrm{u}$ Požegi, također preminuo iste godine. ${ }^{4} \mathrm{U}$ dopisu od 10. prosinca 1834. udovica pokojnog rabina također moli za porezne olakšice u poslovanju. Rabin Krakauer jedan je od prvih Židova koji 1824. godine dobivaju dozvolu stalnog boravka s obitelji u gradu Požegi. On je do svoje smrti 1834. vodio krčmu i konačište za židovske trgovce pod nazivima Koscher-Weinschrank i Juden-EinnehrWirtshaus. Vlasti su mu to dopustile zbog dijeljenja Židova od ostalog stanovništva, a u njegovim krčmama/konačištima jela se košer hrana. Židovi su se na požeškom groblju pokapali 1821. - 1941. godine, a iz obrade matičnih knjiga umrlih proizlazi da je u razdoblju 1858. - 1941. na tome groblju pokopana 401 osoba. Matične knjige umrlih, rođenih i vjenčanih vodio je rabin Krakauer 1821. - 1833., a za period 1833. - 1858. nije poznato koliki je broj pokopanih ni tko je vodio matične knjige.

Godine 1904. rabin dr. Mojsije Margel, uz pomoć trgovaca Davida Freuda i Bernarda Bauera, osniva Društvo ili Bratovštinu Chevra Kadisha čija je osnovna zadaća bila briga o dostojanstvenom ukopu pokojnika te briga o uređenju groblja i grobova. Društvo je vodilo knjigu Zlatna spomenica s imenima umrlih koja su se, sukladno običaju, čitala prigodom četiriju velikih blagdana. Zaslugom Bratovštine groblje je 1906. godine obzidano zidom od kamena i opeke. Na dijelu židovskoga groblja pokapali su se i ljudi muslimanske vjere, te je Bratovština 1930. godine uputila Gradskom načelstvu i Ratnom ministarstvu pravde dopis o potrebi ekshumacije grobova vojnika muslimanske vjere jer je njihovih grobova bilo sve više, a mjesta za ukop Židova sve manje. Nije poznato jesu li se ekshumacije izvele i je li postupljeno prema zahtjevu Bratovštine. Godine 1910. započinje gradnja mrtvačnice na sjevernoj strani groblja, najvjerojatnije prema nacrtu osječkih arhitekata Viktora Aksmana i Ivana Domesa. ${ }^{5}$ Iako nacrt nije ovjeren, gotovo sa sigurnošću možemo ustvrditi da je mrtvačnica građena prema navedenom nacrtu, što dokazuje i detalj s panoramske fotografije grada Požege.

\footnotetext{
4 Sign: HR-DASB-PŽ-2 Poglavarstvo Kraljevskog i slobodnog grada Požege (1765-1848), Opći spisi, kut. 108 , spis $77 / 1835$.

5 Sign: HR-DAOS-495 Zbirka planova i nacrta (1759/1978), Serija II, arh. jedinica 39.2.1, 39.2.2, 39.2.3., 39.2.4.
} 


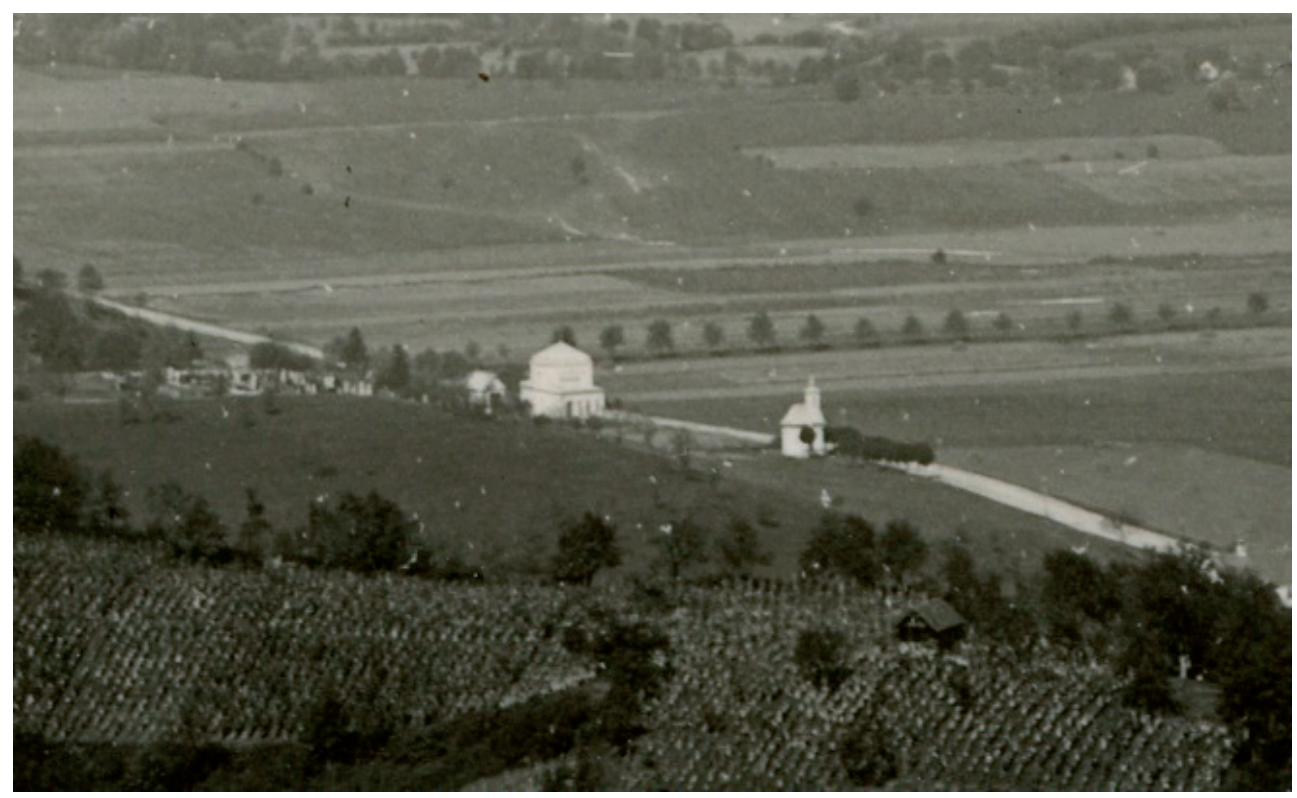

Atelier Wollner, panorama grada Požege, detalj

Prema nacrtu, građevina je bila pravokutnog tlocrta sa središnjom dvoranom koja je bila svođena blago zašiljenom kupolom na kvadratnoj osnovi, na vrhu koje je bila Davidova zvijezda. Oko centralne dvorane nalazili su se prostori, odnosno sobe za pranje pokojnika, soba za svećenika, izba, soba za kola, ali i stan za grobara. Prema detalju s razglednice, vidljivo je da je stan za grobara bio zasebna građevina smještena pokraj mrtvačnice, što potvrđuju i podaci pronađeni u Jevrejskom istorijskom muzeju u Beogradu. Građevina je građena u stilu secesije s jednostavno oblikovanim pročeljima. Središnji dio sjevernog/glavnog pročelja blago je istaknut s centralno smještenim ulaznim vratima i pojasom uskih prozora iznad vijenca. Lijevo i desno od ulaznih vrata nalazio se po jedan profilirani prozorski otvor. Prozorski otvori na južnom pročelju prema groblju bili su uži, bez profilacija, i bila su po tri sa svake strane centralno smještenih vrata. Na južnoj strani, pri ulazu u groblje, nalazio se drvored kestena te nekoliko starijih spomenika. Mrtvačnica je, kao i stan grobara, srušena u svibnju 1941. 


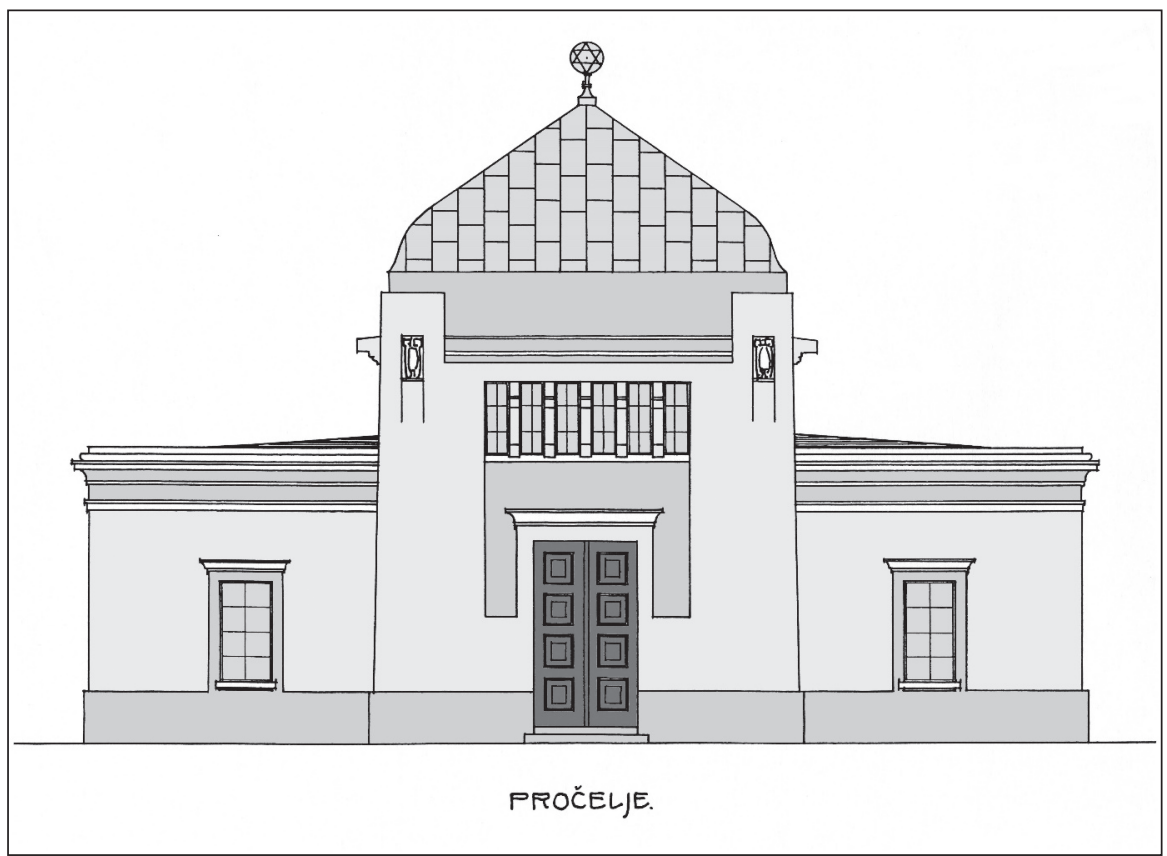

Zgrada mrtvačnice prema nacrtu V. Aksmana i I. Domesa, sjeverno i južno pročelje

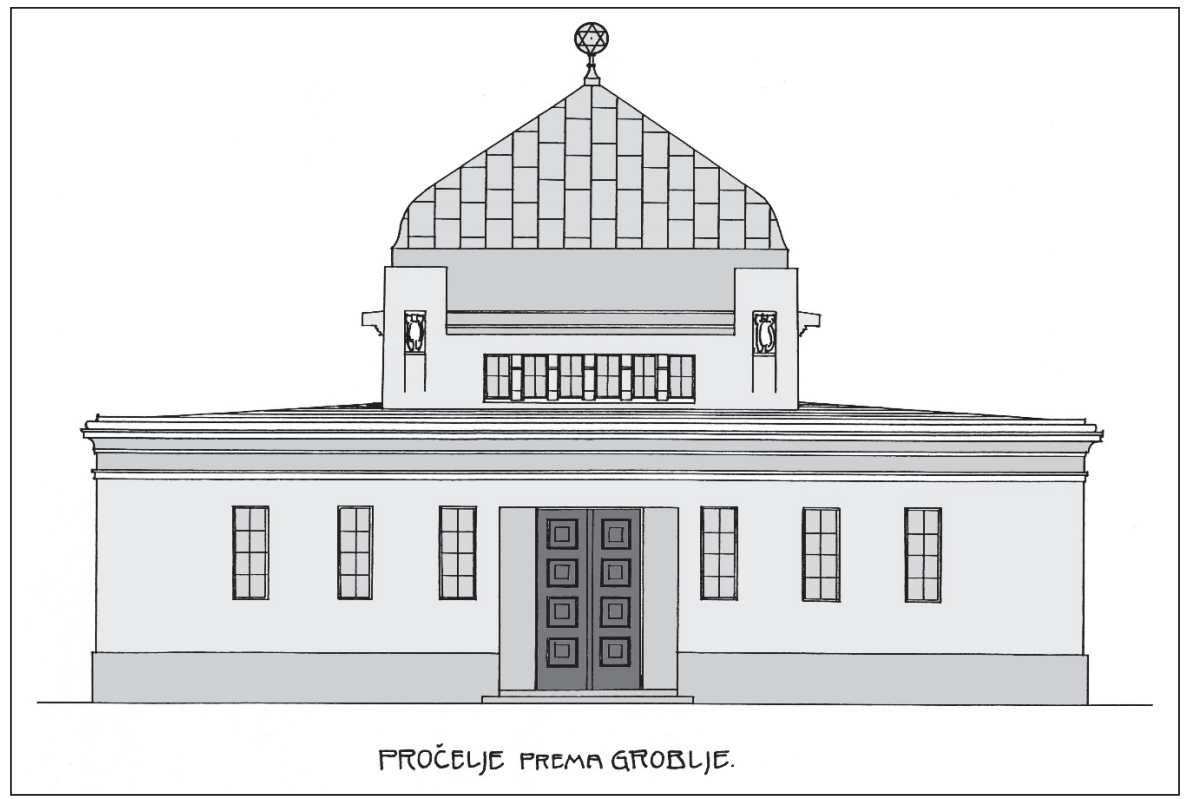




\section{ŽIDOVSKO GROBLJE NAKON DRUGOGA SVJETSKOG RATA}

Nakon rušenja mrtvačnice židovsko je groblje bilo prepušteno vandalizmu i propadanju te nebrizi lokalne zajednice. Tek se 50-ih godina 20. stoljeća javlja potreba za uređenjem i spašavanjem groblja. U svibnju 1953. godine Manfred Sternberg, Židov porijeklom iz Požege, a nastanjen u New Yorku, nakon posjeta Požegi i židovskom groblju upućuje Savezu jevrejskih opština Jugoslavije u Beogradu (u daljnjem tekstu Savez) dopis u kojemu ga izvještava o stanju groblja. Od Saveza traži odgovor o mogućnosti uređenja groblja i postavljanja žičane ograde, koju je voljan i sam poslati, upozoravajući pri tome na činjenicu da je većina spomenika vrlo vrijedna, izrađena od švedskoga granita. Istovremeno ističe potrebu izmještanja najstarijih spomenika koji su se nalazili u donjem, starom dijelu groblja, nedaleko od mrtvačnice. Savez je Gradskom narodnom odboru (GNO) u Požegi uputio pitanje o mogućnosti uređenja židovskoga groblja, pri čemu je ponudio i novčanu pomoć za podizanje nove ograde, koja je potpuno uništena kao i mrtvačnica. Nakon zajedničkog sastanka predstavnika Saveza i GNO-a postignut je zajednički dogovor oko uređenja groblja, pri čemu bi se prednja i desna strana groblja zatvorila zidom od opeke, dok bi gornja lijeva strana trebala biti zatvorena živom ogradom isprepletenom žicom i drvenim stubovima. Planirano je i formiranje ulaza, kao i sadnja zelenila (tužna vrba, tuja i topola) i cvijeća, svi porušeni spomenici trebali su se vratiti u prvobitno stanje, nagnuti spomenici ispraviti, a oštećeni popraviti. Narodni odbor obvezao se da će ubuduće voditi brigu o uređenju groblja i o očuvanju imovine. Između ostalog, dogovorena je i prodaja neiskorištenog dijela groblja - zemljišta na kojemu se nekada nalazila mrtvačnica i stan čuvara groblja, sve do drvoreda kestena, a dobivenim novcem od prodaje saniralo bi se groblje. GNO se obvezao da će obaviti geodetsku izmjeru zemljišta, a predstavnika Saveza - Josipa Herzla, posljednjeg Židova u Požegi - 1954. godine obvezuje da potraži potencijalne interesente za kupovinu zemljišta. Godine 1955. Josip Herzl sklapa ugovor s Autosaobraćajnim poduzećem Požega (APP), o čemu izvještava Savez, te navodi kako se trava na groblju ponekad kosi. Godine 1957. godine Herzl obavještava Savez kako APP ne izvršava svoje obveze prema ugovoru zbog financijske nemogućnosti te odustaje od kupovine zemljišta s obzirom na to da, prema urbanističkom planu, nije dozvoljena gradnja garaže i radionice. Nakon propalog dogovora s APP-om, Narodni odbor predlaže Savezu da proda zemljište te da iznos uplati na račun Općine, a da zemljište, odnosno građevinske parcele, ako ih ne uspije prodati, vlasnički, o svom trošku, prenese na Općinu Slavonska Požega kao naknadu za uređenje i održavanje groblja. Savez se složio s predloženim, osim s idejom snošenja troškova oko prijenosa vlasništva. Godine 1959. Narodni odbor Općine Slavonska Požega prodao je zemljište kao građevno s tim da je zadržana potrebna širina oko $3 \mathrm{~m}$ od nogostupa do groblja predviđena za 
Radovi Zavoda za znanstveni i umjetnički rad u Požegi, 7 (2018), str. 137-153 M. Bender Maringer: Groblje Izraelitičke bogoštovne općine u Požegi
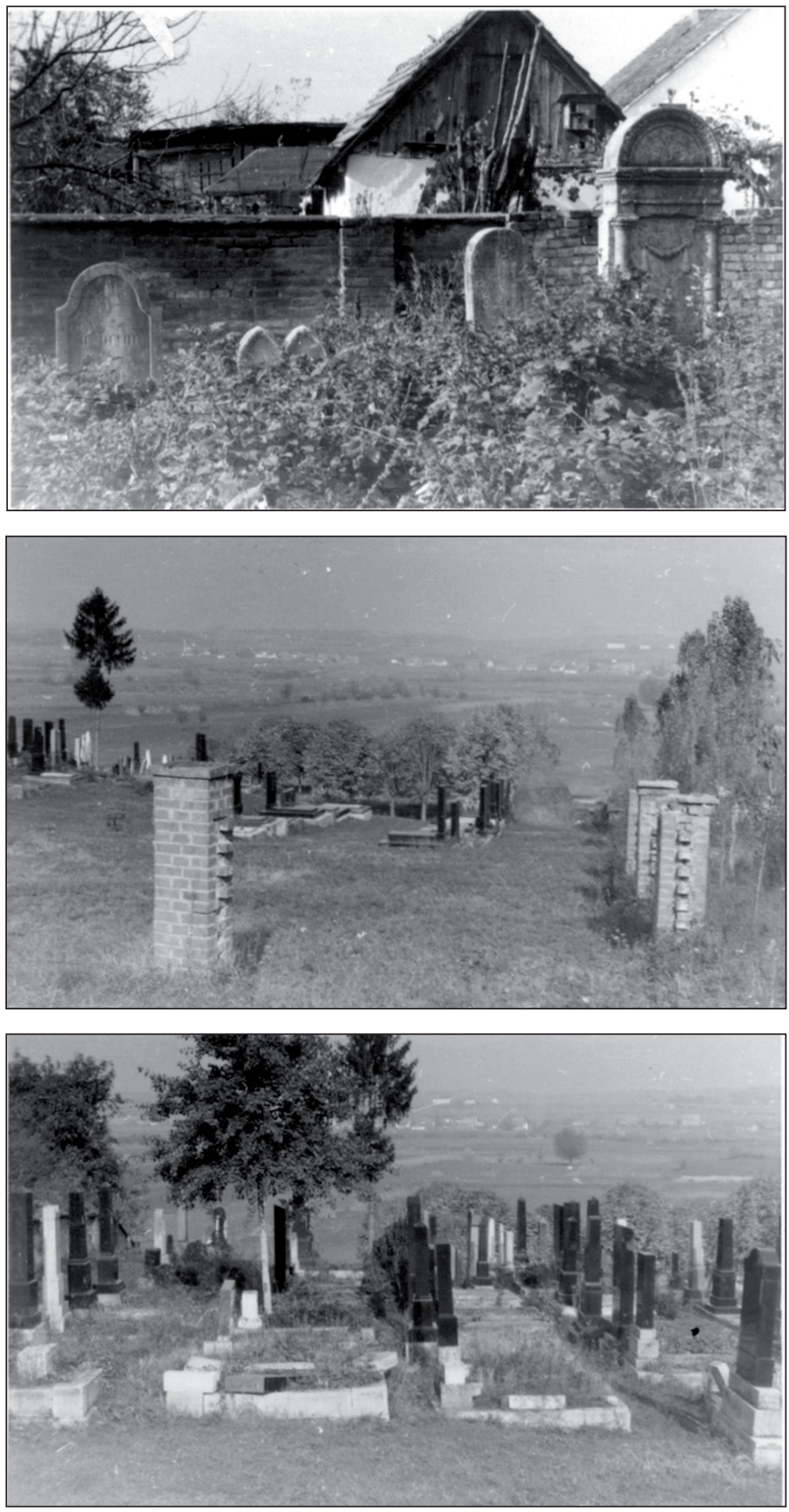

Židovsko groblje u Požegi 50-ih godina 20. stoljeća (fototeka Jevrejskog istorijskog muzeja u Beogradu) 
ulaz, a od dobivene svote općina se obvezala održavati groblje, no u godinama koje su uslijedile, iz korespondencije između Saveza i Općine Požega, vidljivo je da se groblje nije uređivalo niti je podignuta ograda. Godine 1969. Komunalno poduzeće Slavonska Požega dopisom izvještava Savez o tome da se groblje nalazi u zapuštenom stanju, da je otvoreno sa svih strana i izloženo kao pašnjak, a da su spomenici u takvom stanju da predstavljaju opasnost, te da ono ne odgovara osnovnim urbanističkim normama i sanitarnim uvjetima. Komunalno poduzeće predložilo je izgradnju spomen-kosturnice umjesto dotadašnjega groblja, a kako ni jedna ni druga strana nisu imale sredstva za sanaciju, kao rješenje su predložili ekshumaciju grobnih mjesta i prodaju granitnih spomenika, čime bi se kompenzirali troškovi izgradnje i održavanja.

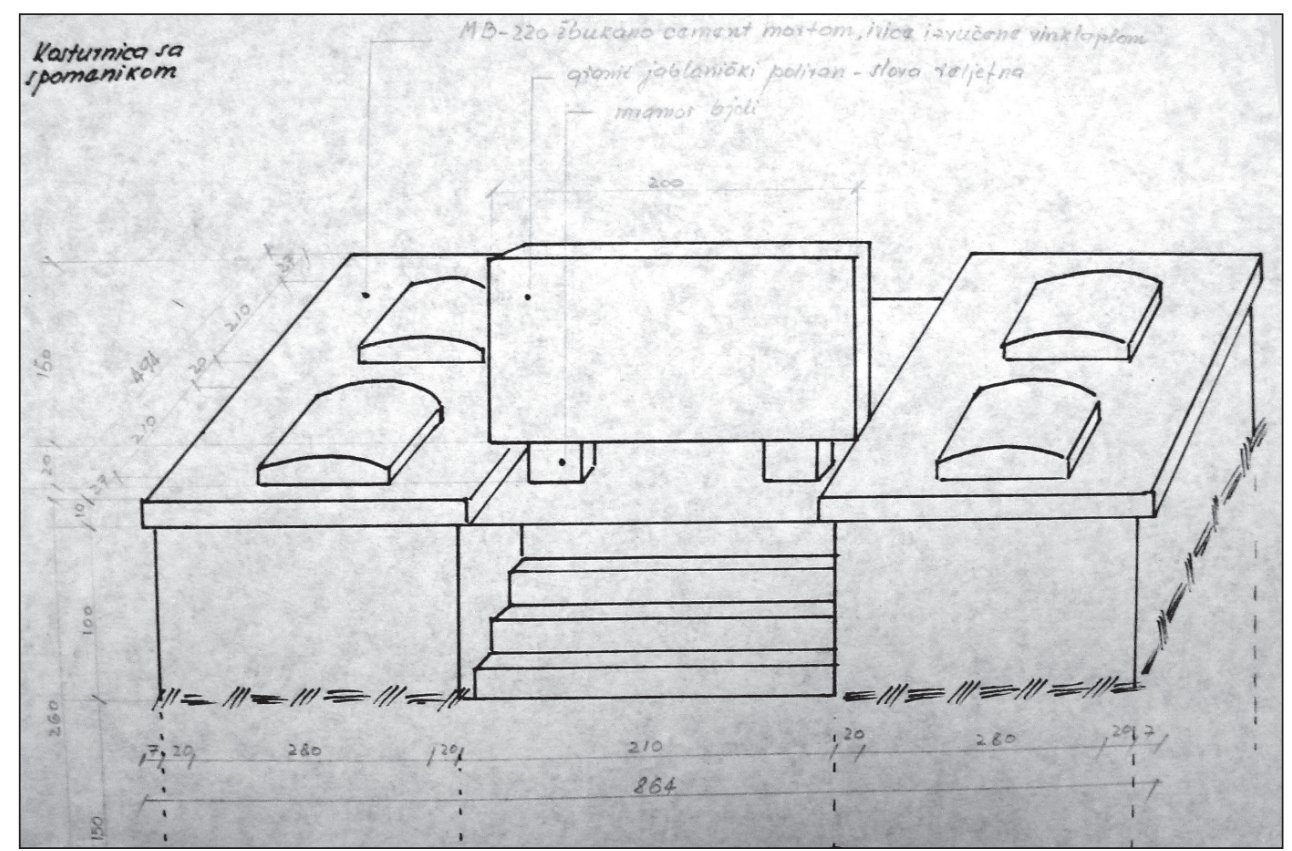

Skica kosturnice sa spomenikom (Jevrejski istorijski muzej u Beogradu, arhivska građa Saveza jevrejskih opština)

Organizacija jugoslavenskih Židova na taj je prijedlog reagirala slanjem protestnog telegrama Općinskoj skupštini, koja je u međuvremenu na sjednici 2. prosinca 1969. donijela rješenje o stavljanju židovskoga groblja izvan upotrebe, te je ono uknjiženo kao društveno vlasništvo s pravom korištenja Općine Slavonska Požega. Savez je pozvao sve zainteresirane pojedince - potomke u Jugoslaviji, Americi i Izraelu - 
da se do 31. ožujka 1971. izjasne oko ekshumacije grobova i prenošenja spomenika na gornji plato o vlastitom trošku. Budući da se oko predloženog uređenja groblja ništa nije moglo poduzeti bez pristanka rodbine pokopanih na židovskom groblju, a koji su takav prijedlog sanacije - ekshumacije smatrali pokušajem likvidacije groblja, Općina Slavonska Požega ideju oko uređenja groblja u cijelosti je prepustila Savezu, odnosno potomcima požeških Židova. Vijest o pokušaju likvidacije groblja objavljena je i u članku Jevrejskog pregleda iz godine 1970., str. 35. U godinama koje su uslijedile pa sve do ranih 80-ih pitanje uređenja židovskoga groblja bilo je i dalje aktualno, a jedna od posljednjih ideja upućenih Savezu bilo je prekopavanje groblja, formiranje aleje od zatečenih nadgrobnih spomenika s centralnom spomen-pločom na kojoj bi bila uklesana imena svih pokopanih. Ideja kao takva nikada nije zaživjela, kao ni dogovor između Saveza i Općine.

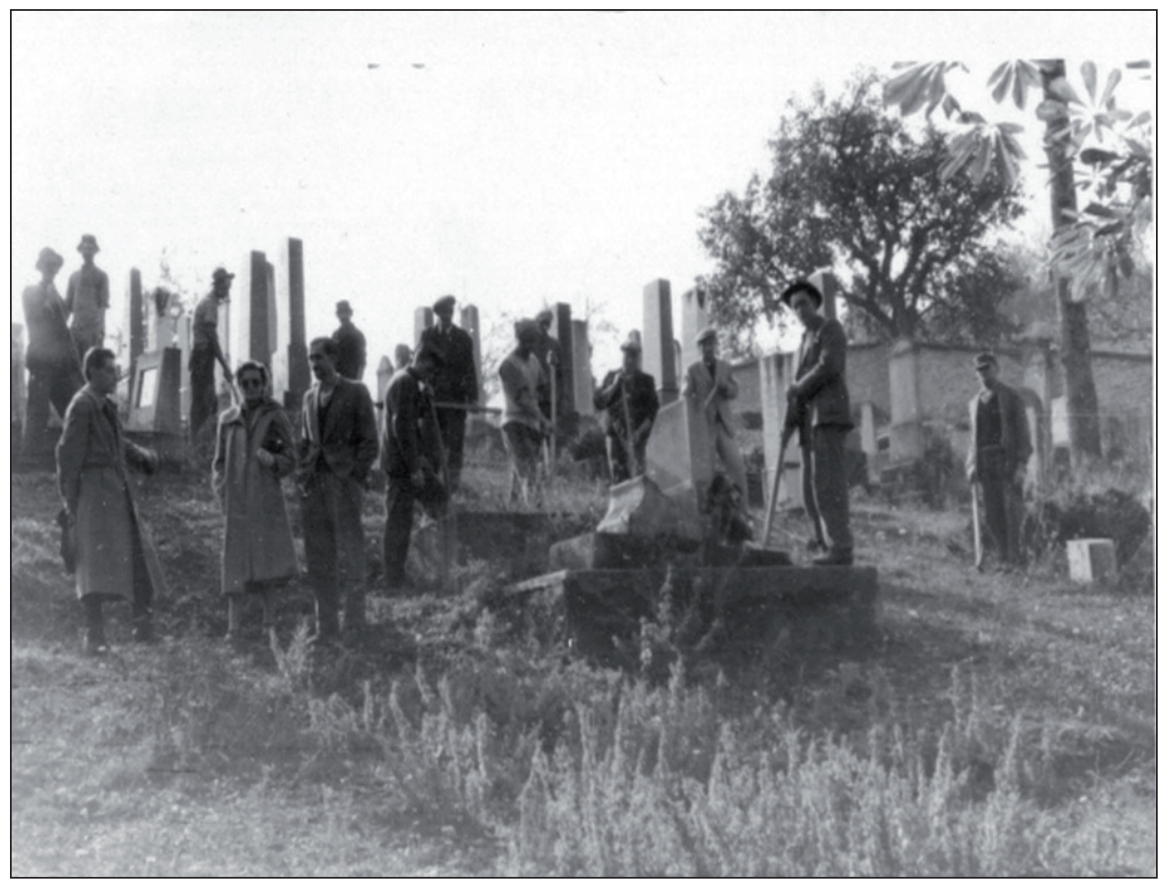

Čišćenje židovskoga groblja 50-ih ili 60-ih godina 20. stoljeća (fototeka Jevrejskog istorijskog muzeja u Beogradu) 


\section{KONZERVATORSKA ISTRAŽIVANJA I OBNOVA ŽIDOVSKOGA GROBLJA}

Nakon dugogodišnje nebrige i izostanka bilo kakve inicijative i potrebe za uređenjem groblja, 2004. godine Konzervatorski odjel u Požegi započinje sustavno dokumentiranje židovskoga groblja u smislu popisivanja i fotografiranja svakoga pojedinoga grobnog mjesta i spomenika, što je ponekad uključivalo čišćenje i pranje pojedinih spomenika kako bi se natpisi mogli očitati i kvalitetno fotografirati. Utvrđen je broj od 154 grobna mjesta i oko 200 pokopanih. Grobnice su bile poredane $\mathrm{u}$ otprilike deset redova, sudeći prema datacijama na spomenicima, stari dio groblja bio je na zapadnoj strani, dok su se novije grobnice nalazile na istočnoj strani, i to uglavnom iz 40-ih godina 20. stoljeća. Najstariji je grob, sudeći prema očuvanom natpisu, iz 1860. (Karl Hecht).

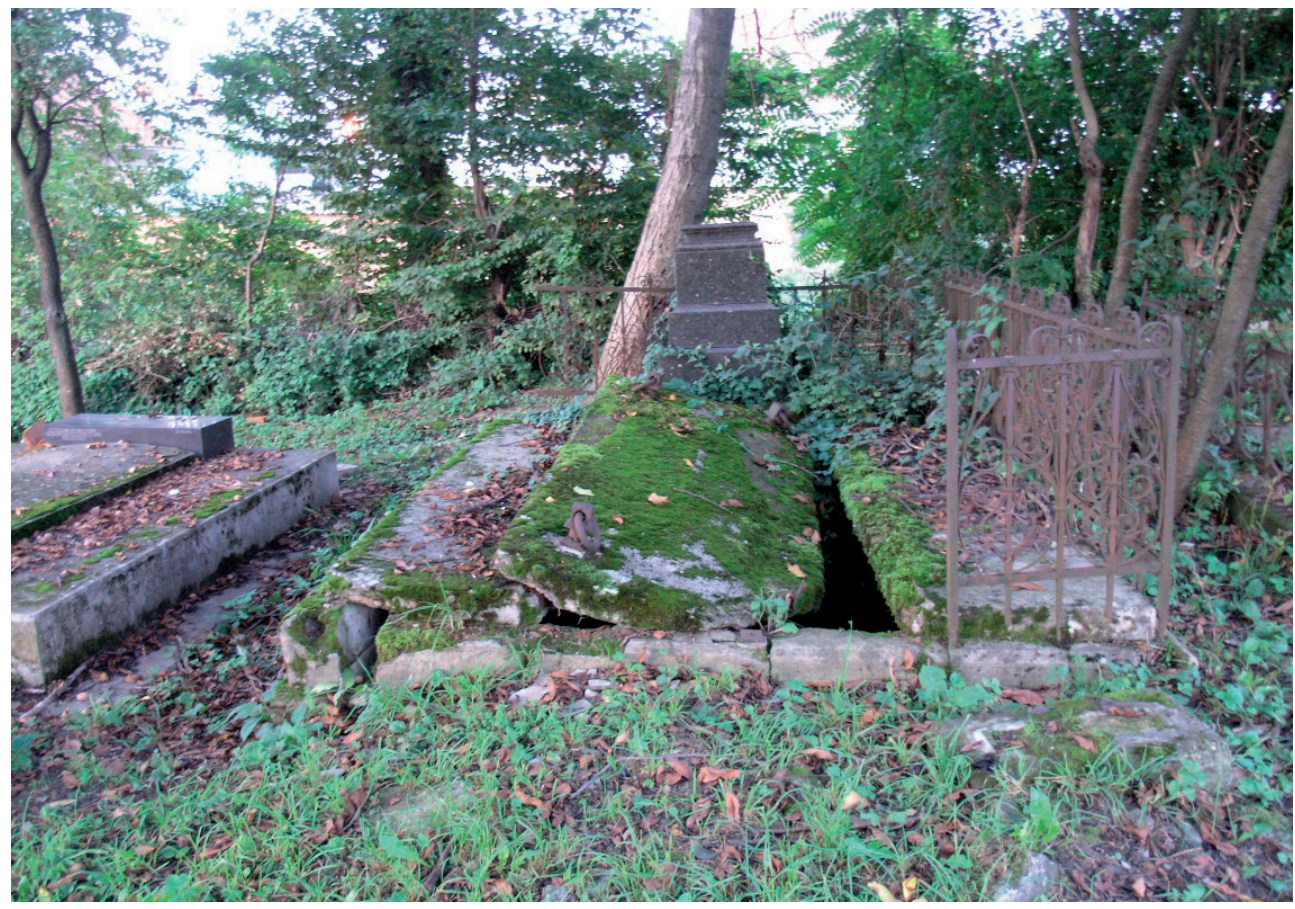

Grobnica obitelji Schorsch (fototeka KO Požega) 


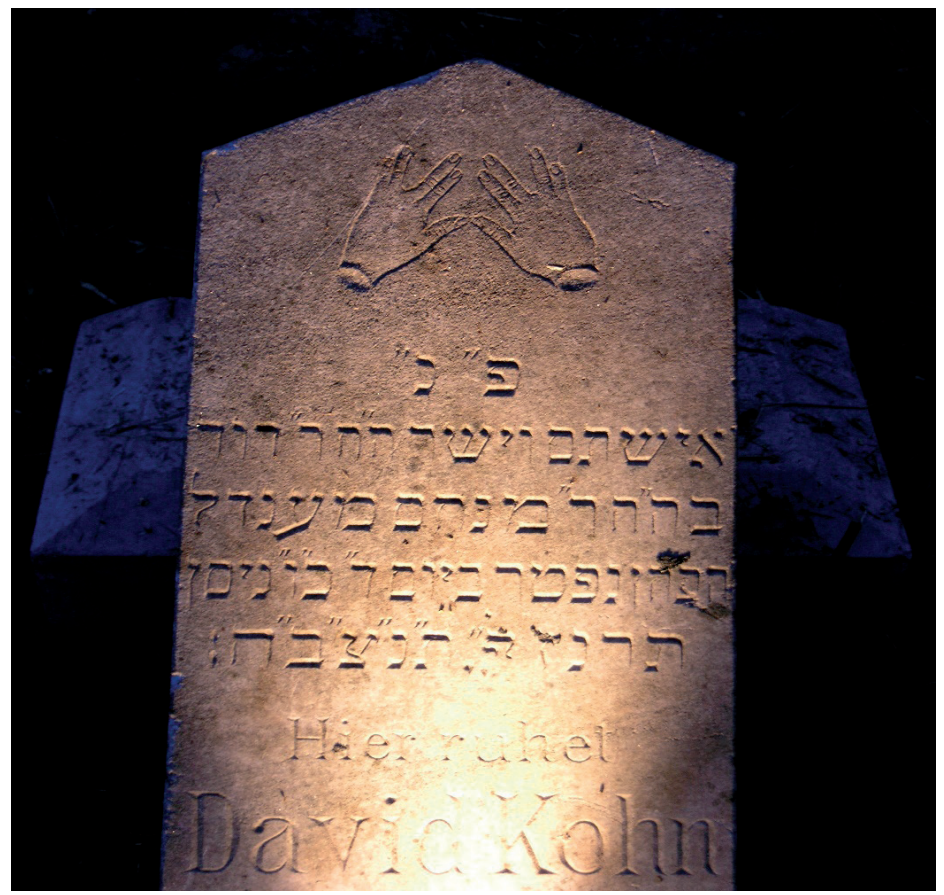

Fotografiranje i pranje spomenika (fototeka KO Požega)

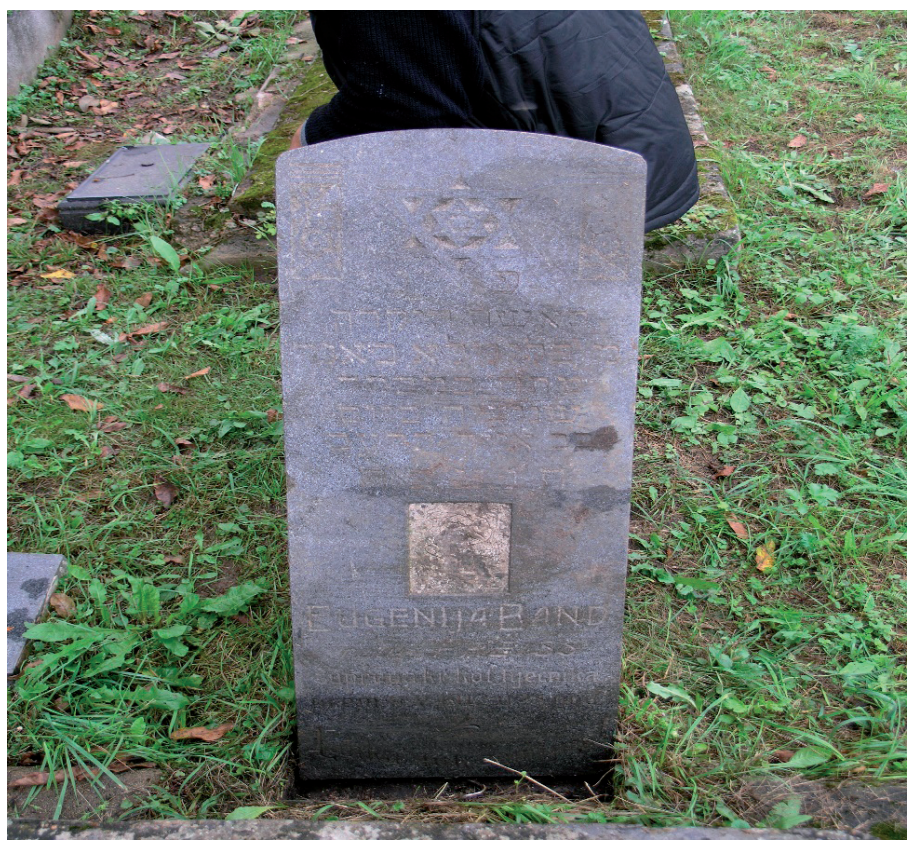


Spomenik ili maceva postavljao se na grob u pravilu nakon 12 mjeseci, grobnice, odnosno spomenici izrađeni su od mramora, granita, betona i pješčara i tek manji dio njih ima očuvane fotografije pokojnika. Na groblju su pokopane obitelji Bienenfeld, Schwarz, Weiss, Muller, Schorsch, Rosenfeld, Fischer, Kohn, Hecht, Dorner itd. Mnogi od njih bili su istaknuti članovi židovske zajednice koji su svojim djelovanjem značajno utjecali na gospodarski i kulturni život grada Požege. Natpisi su na spomenicima na hrvatskom, hrvatskom i hebrejskom te hebrejskom i njemačkom. Kvalitetni, mramorni i granitni spomenici u obliku su piramide, većina pri vrhu ima natpis na hebrejskom po nikhbar, što znači ovdje leži/počiva. Spomenici su ukrašeni religijskim, simboličnim i dekorativnim motivima poput Davidove zvijezde, žalosne vrbe, slomljene ruže itd. Sve su spomenici „licem“ okrenuti prema istoku. $\mathrm{Na}$ temelju gore navedenih istražnih radova Konzervatorski odjel u Požegi donio je 2004. godine Rješenje o preventivnoj zaštiti, a nakon isteka preventivne zaštite groblje je zaštićeno i upisano u Registar kulturnih dobara RH pod brojem Z-3191. Grad Požega, Gradsko poglavarstvo, u suradnji s Konzervatorskim odjelom 2005. godine započeo je radove na projektnoj dokumentaciji, a kasnije i radove na rekonstrukciji groblja prema projektu tvrtke Plan-Projekt d.o.o. iz Požege temeljenom na konzervatorskim smjernicama.

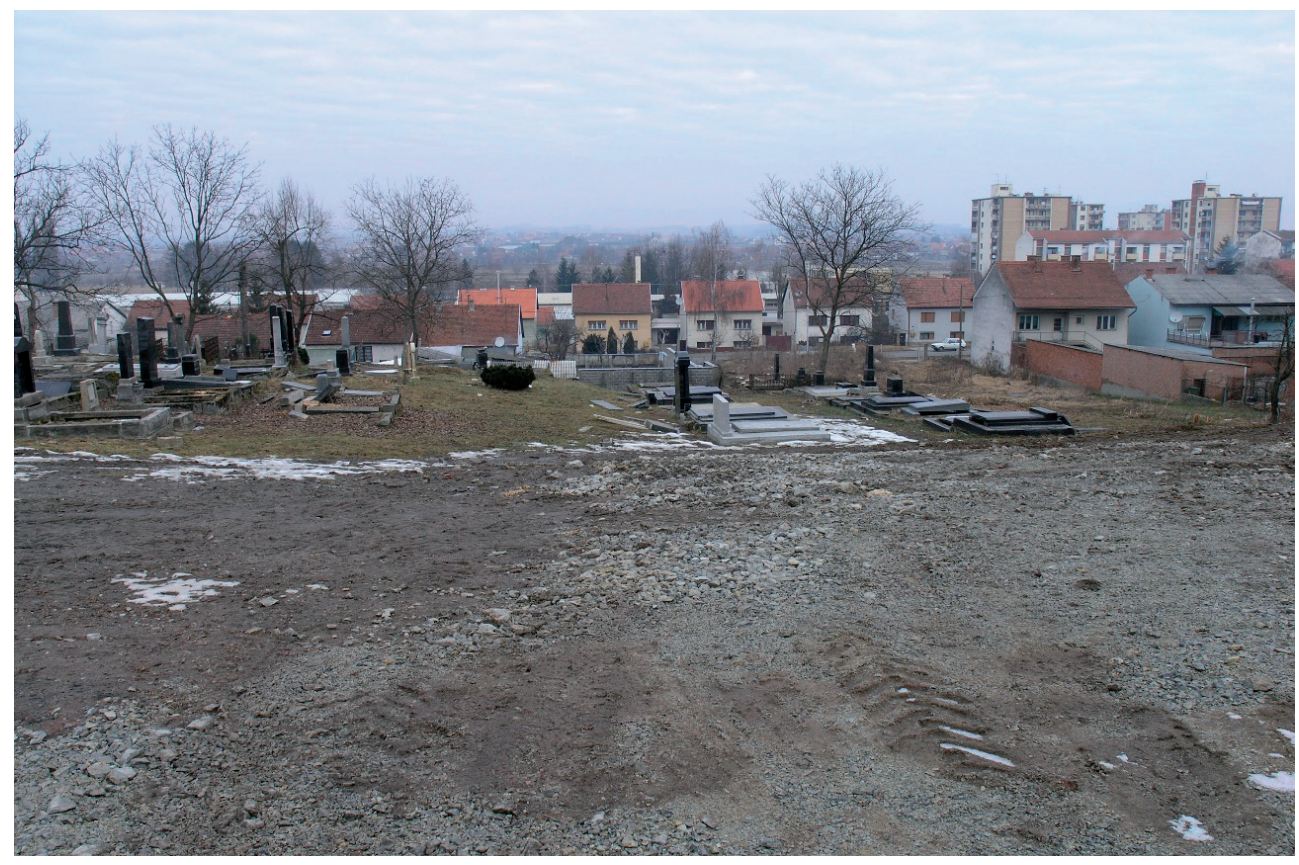

Početak radova na obnovi židovskoga groblja (fototeka KO Požega) 
Osnovna ideja obnove prema konzervatorskim smjernicama bila je prije svega sanacija zapuštenih i oštećenih grobova, što je zahtijevalo pažljivo vraćanje grobnih ploča, podizanje spomenika na njihova mjesta pod nadzorom konzervatora i sanacija betonskih okvira oko grobnih mjesta. Prostor groblja bilo je potrebno ograditi zidom na način koji je vidljiv na povijesnoj fotografiji J. Kempfa; zid se trebao zidati opekom punog formata i biti glatko ožbukan, dok su stubovi ostavljeni neožbukani. Prije podizanja zida bilo je potrebno sanirati teren na sjevernoj i istočnoj strani te izvesti potporni zid na sjevernoj strani kako bi se nivo terena podigao na visinu grobnih mjesta. Formirana su dva ulaza - glavni na južnoj strani smješten na sredini ogradnog zida u koji su se ugradila postojeća dvokrilna kovanoželjezna vrata te sporedni pješački ulaz na sjevernoj strani u koji se ugradila nova kovanoželjezna ograda.

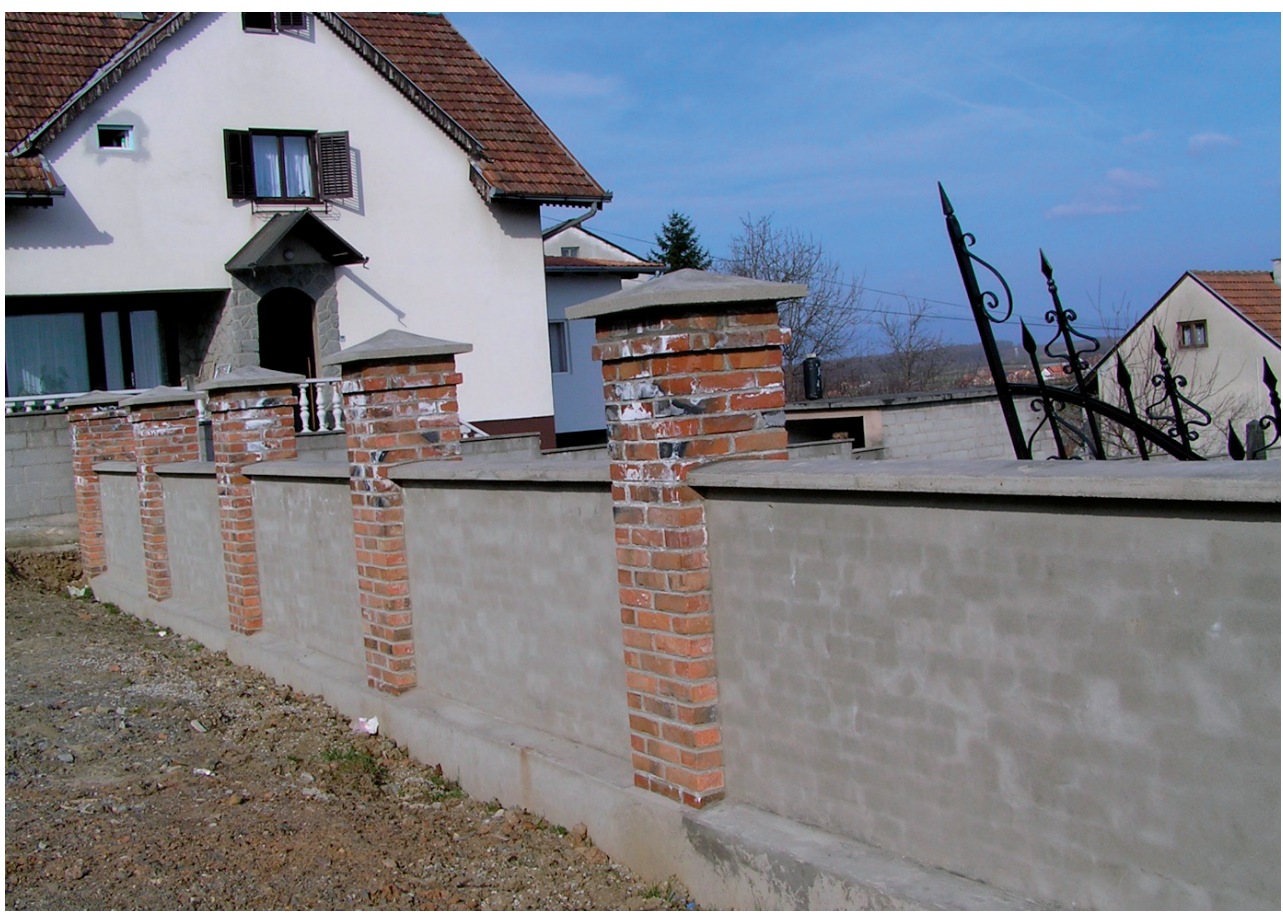

Rekonstrukcija zida na južnoj strani židovskoga groblja (fototeka KO Požega)

Ulazi su naglašeni stubovima izgledom prema povijesnoj fotografiji s ugrađenom po jednom okruglom svjetiljkom. Na južnoj strani, ispred glavnog ulaza, formirano je parkiralište. Unutar groblja izveden je ulazni plato s kojeg se dalje račvaju horizontalne i vertikalne staze različite širine koje prate postojeći teren te ujedno omogućuju pristup vozilima prilikom održavanja i uređenja groblja. Vanjski rubovi 
staza uređeni su betonskim rubnjacima, a same staze izvedene su agregatom frakcije $0-8 \mathrm{~mm}$. Na pojedinim dijelovima staza zbog prevelikog nagiba terena izvedene su stepenice kako bi se prevladala visinska razlika. Groblje je i hortikulturno uređeno, tako da je postojeće zelenilo poput stabala oraha, višnje i kestena uglavnom porušeno, te je zasađeno zelenilo primjereno groblju i određene vrste niskog raslinja. Po završetku radova, 2007. godine na židovskom groblju svečano je obilježen Dan sjećanja na žrtve holokausta uz nazočnost tadašnjeg predsjednika Stjepana Mesića, predstavnika Židovske zajednice u Hrvatskoj, Židova s područja bivše Jugoslavije, lokalne vlasti i građana Požege. Nakon dugog vremena na groblju je izmoljen i kadiš, židovska molitva za mrtve.

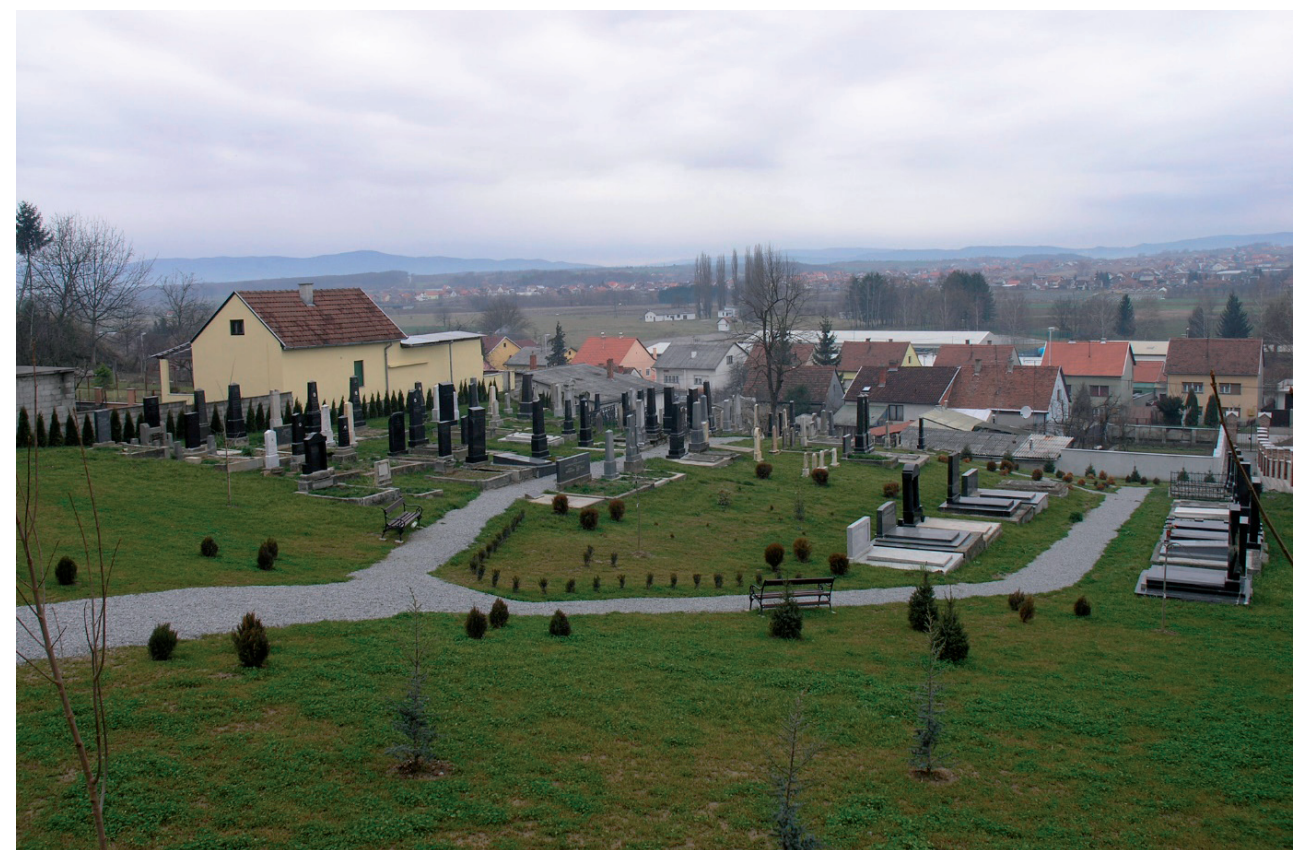

Židovsko groblje u Požegi nakon obnove (fototeka KO Požega)

\section{Zaključak}

Pojam baštine nije određen samo svojom povijesnom, arheološkom ili umjetničkom vrijednosti nego on po svojoj prirodi u sebi sadržava dodatnu, memorijsku vrijednost važnu za budućnost čovjeka i njegove zajednice. Židovska groblja čine posebno poglavlje u povijesti razaranja u vrijeme Drugoga svjetskog rata, a i kasnije. Očuvanje starih groblja neovisno o tome kojoj vjerskoj zajednici pripadaju, predstavlja civilizacijski nivo, pri čemu je izražena potreba za multidisciplinarnim 
pristupom prilikom obnove, što bi uključivalo suradnju lokalne zajednice i struke - povjesničara, povjesničara umjetnosti, genealoga i sličnih srodnih zanimanja, s definiranim metodama konzervacije. Obnova židovskih groblja u svijetu prepoznata je kroz volontersko djelovanje, udruge ili neprofitne fondacije poput Heritage Foundation for Preservation of Jewish Cemeteries (HFPJO) - AVOYSEINU koja pomaže $\mathrm{u}$ obnovi židovskih groblja na području istočne Europe. U idealnim uvjetima obnova starih groblja trebala bi se temeljiti prije svega na povijesnim istraživanjima, stručnoj obnovi spomenika (pažljivo čišćenje i popravljanje, pranje spomenika destiliranom vodom, upotreba mekanih četki itd.) i njihovoj valorizaciji, detaljnom fotografiranju i planu održavanja koji vrlo često nakon provedene obnove izostane. Sve se više nameće problem održavanja stanja kulturnog dobra nakon obnove jer vlasnici često nemaju jasan financijski plan ni ideje o rehabilitaciji kulturnog dobra i njegovoj održivosti, posebice kada je riječ o starim grobljima koja su izvan funkcije. Vrlo važnu ulogu u tome igra edukacija i senzibilizacija lokalne zajednice kroz predavanja i radionice te uvrštavanje povijesnih groblja, u ovom slučaju židovskoga, u turističku ponudu grada. Stara groblja predstavljaju lokalnu povijest, spomenici sadrže imena i prezimena ljudi od kojih su neki bili bitni u formiranju društvenog, političkog ili kulturnog života te govore o kulturi toga vremena i danas gotovo zaboravljenim simboličnim motivima. Groblja su velik izvor podataka onima koji istražuju povijest svoje obitelji ili povijesti grada, posjetitelje upoznaju s drugačijom kulturom, no prije svega govore o krhkosti života, neprekidnom ciklusu rođenja, života i smrti kojega smo i sami dio.

\section{Literatura}

Kempf, Julije (1910): Požega: zemljopisne bilješke iz okoline i prilozi za povijest slob. i kr. Grada Požege i Požeške županije.

Žugaj, Vjekoslav (2001): Židovi novogradiškoga kraja, Židovska općina Zagreb, Zagreb.

Državni arhiv u Sl. Brodu - Odjel u Požegi: Poglavarstvo Kraljevskog i slobodnog grada Požege (1765-1848), Opći spisi.

Državni arhiv u Osijeku: Zbirka planova i nacrta (1759/1978), Serija II, arh. jedinica 39.2.1, 39.2.2, 39.2.3., 39.2.4.

Glasnik županije požeške, Požega, br. 43.

Jevrejski istorijski muzej u Beogradu, Arhivska građa Saveza jevrejskih opština iz perioda nakon 1945.

Jevrejski pregled, godina XXI, Beograd, 1970., broj 11-12, str. 35.

Dokumentacija Ministarstva kulture, Uprave za zaštitu kulturne baštine, Konzervatorskog odjela u Požegi. 


\section{The Cemetery of the Israelite Religious Municipality in Požega}

\section{Summary}

The paper follows the fate of Israelite/Jewish cemetery in Požega from its founding, over the period of devastation and the attempt of liquidation, to its final reconstruction and restoration in 2006. Israelite cemetery in Požega presents nearly the sole memory of the formerly rather numerous Jewish community, which played a major role in the economic, cultural and social life of the town of Požega in the time span between the end of the $18^{\text {th }}$ century and World War Two. The paper mostly relies on the archive material of Croatian State Archives in Osijek, the State Archives in Slavonski Brod - Department in Požega, and Hebrew Historical Museum in Belgrade. The initial attempts to restore the cemetery date back to the 1950s, when the descendants of the Jews from Požega turned to the National Committee of the Municipality of Požega with the request for the cemetery to be renovated. This had however not been realised before 2005. The conservation research of Jewish cemetery commenced in 2004, and it included systematic cataloguing, photographing and identifying the monuments in situ, along with the study of Jewish death registers. Thereby, the basis for drafting project documentation for the reconstruction of the cemetery was set. The cemetery has eventually been restored and put under protection as a cultural good of the Republic of Croatia.

Keywords: Israelite/Jewish cemetery; restoration; conservation research.

Marina Bender Maringer, dipl. pov. umjetnosti

Ministarstvo kulture Uprava za zaštitu kulturne baštine

Konzervatorski odjel u Požegi

Trg Matka Peića 3, 34000 Požega

Marina.Bender-Maringer@min-kulture.hr 
